\title{
SEM studies on the leaf indumentum of six Melastomataceae species from Brazilian Cerrado ${ }^{1}$
} Microscopia eletrônica de varredura do indumento foliar de seis espécies de Melastomataceae do cerrado

\author{
Camilla Rozindo Dias Milanez ${ }^{2} \&$ Silvia Rodrigues Machado ${ }^{3}$
}

\begin{abstract}
The wide diversity of their trichomes, which vary from simple unicellular to very complex structures, is a remarkable characteristic in Melastomataceae. This paper characterizes the leaf indumentum of Miconia albicans (Sw.) Triana, M. chamissois Naudin, M. fallax DC., M. ligustroides (DC.) Naudin, Microlepis oleaefolia (DC.) Triana and Rhynchanthera dichotoma DC., typical species from Brazilian cerrado. Samples collected from the median third of young and mature leaf blades were processed following the usual scanning electron microscopy techniques (SEM). We observed ten morphological types of trichomes and four of emergences. With five different types, four of which are reported for the first time, Rhynchanthera dichotoma is the species that presents the most diverse indumenta. A mixed type of trichome formed by a glandular and a branched non-glandular portion called "lateral-gland" was observed in M. ligustroides. Such non-glandular portion presents different degrees of development. A correlation is suggested between the stage of development of the non-glandular portion and the exposition to light of these "lateral gland" on young leaves.
\end{abstract}

Key words: emergence, leaf, trichome, morphology.

\section{Resumo}

A grande diversidade de tricomas, variando desde estruturas unicelulares a tricomas muito complexos é uma característica marcante em Melastomataceae. Este trabalho caracteriza o indumento foliar de Miconia albicans (Sw.) Triana, M. chamissois Naudin, M. fallax DC., M. ligustroides (DC.) Naudin, Microlepis oleaefolia (DC.) Triana e Rhynchanthera dichotoma DC., espécies típicas do cerrado brasileiro. Amostras retiradas do terço mediano do limbo de folhas jovens e adultas foram processadas segundo técnicas usuais para microscopia eletrônica de varredura (MEV). Verificaram-se dez tipos morfológicos de tricomas e quatro de emergências. Rhynchanthera dichotoma foi a espécie que apresentou maior diversidade de indumento, cinco, sendo que destes, quatro foram registrados pela primeira vez. Um tipo misto de tricoma constituído por uma porção glandular e outra não-glandular ramificada, denominado de "lateral-gland", foi observado em M. ligustroides. A porção não-glandular apresentou diferentes graus de desenvolvimento. Sugere-se uma correlação entre o grau de desenvolvimento da porção não-glandular e a exposição à luz destes tricomas em folhas jovens.

Palavras-chave: emergência, folha, tricoma, morfologia.

\section{Introduction}

Melastomataceae is the largest family of Myrtales, with 166 genera and approximately 4,570 species, predominantly distributed in tropical and subtropical regions (Clausing \& Renner 2001). In Brazil, it is one of the most representative families of the Cerrado flora, with about 237 species, predominantly shrubs (Mendonça et al. 1998).
According to Wurdack (1986), Melastomataceae present the most diverse indumentum types among the angiosperms, even though only about $11 \%$ of the neotropical species have been studied. The type of indumentum and the morphology of trichomes are important to classify Melastomataceae and circumscribe their genera and species (Wurdack 1986; Guimarães \& Martins

\footnotetext{
'Part of the first author's doctoral dissertation. Programa de Pós-graduação em Ciências Biológicas, Universidade Estadual Paulista.

${ }^{2}$ Universidade Federal do Espírito Santo, Depto. Ciências Biológicas, Setor de Botânica, Av. Fernando Ferrari 514, 29075-910, Vitória, ES, Brasil. Corresponding author: camilla.milanez@gmail.com

${ }^{3}$ Universidade Estadual Paulista, Instituto de Biociências, Depto. Botânica, C.P. 510, 18618-000, Botucatu, SP, Brasil.
} 
1997; Guimarães et al. 1999), and often allow to recognize species even in a vegetative state (Guimarães \& Martins 1997).

Studies on leaf indumentum usually analyze dried mature leaves of herbarium specimens, which may lead to erroneous interpretations since some trichomes are persistent while others fall during leaf development (Uphof 1962). In addition, the distinction between the types of trichomes and the structure of the indumentum is not often clearly drawn in the literature. Such distinction is important in an ecological context because it is likely that environment has a greater influence on indumentum modifications than on changes in the type of trichome (Johnson 1975). Developmental patterns are not easily categorized since trichomes are produced on almost all plant organs at various stages of their development. Trichome production may continue through ontogeny, and as a consequence, different kinds of trichomes may be produced at different degrees of development (Hammond \& Mahlberg 1973; Johnson 1975). Evidence from the ontogenetic and developmental studies indicate that pubescence is related to genetic control and environmental factors, especially to availability of water regimes and radiation, since it is stimulated by red and inhibited by far-red radiation, as a typical example of the phytochrome reaction (Johnson 1975; Gitz \& Liu-Gitz 2003). Usually, leaves developing in environments with high radiation tend to show high trichome density (Crawley 1997; Sandquist \& Ehleringer 1997).

In this paper, we characterized the leaf indumentum of young and mature leaves of Melastomataceae species occurring in the Brazilian Cerrado as a framework for taxonomic and ecophysiological studies.

\section{Material and Methods}

\section{Plant material}

Studied species are: Miconia albicans (Sw.) Triana, Miconia chamissois Naudin, Miconia fallax DC., Miconia ligustroides (DC.) Naudin, Microlepis oleaefolia (DC.) Triana and Rhynchanthera dichotoma DC. They were selected because of their importance index at a well-preserved fragment of cerrado located at the "Palmeira da Serra Reserve" in the township of Pratânia, state of São Paulo

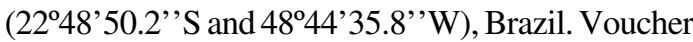
specimens were deposited at the Herbarium of the Department of Botany (BOTU), Botucatu Campus, Universidade Estadual Paulista, Brazil. Each species data are listed in Table 1.

\section{Study site}

The study site is a seasonal savanna referred as Cerrado (Oliveira \& Marquis 2002). This biome is extremely variable in physiognomy and ranges from open grasslands to forests with a discontinuous layer of deciduous and ever-green trees with a low and shrubby growth form. Most trees and shrubs have thick bark, twisted trunks and scleromorphic leaves (Franco 2002). Soils are deep, strongly acid dystrophic latosols, with high aluminum contents. Climate is $\mathrm{Cwb}$ (mesothermal with dry winters) according to Köppen's (1931) classification. The warmest month presents an average temperature inferior to $22^{\circ} \mathrm{C}$, and July is the coldest and driest month of the year. Annual rainfall is $1,534 \mathrm{~mm}$, with a distinct dry season from May to September (81-89 mm, respectively). Average (diurnal) relative humidity is around $80 \%$ during the rainy season, but it drops to 55\% during the dry season when daily minimum relative humidity reaches values around $15 \%$. Mean annual temperature is about $20,3^{\circ} \mathrm{C}$.

Table 1 - Melastomataceae species studied and their respective environment at cerrado vegetation, habit and herbarium record.

\begin{tabular}{lllc}
\hline Species & Environment & Habit & BOTUHerbarium \\
\hline Miconia albicans (Sw.) Triana & Cerrado stricto sensu & Shrub & 24,283 \\
Miconia chamissois Naudin & Border of gallery forest & Shrub & 24,284 \\
Miconia fallax DC. & Cerrado stricto sensu & Shrub & 24,285 \\
Miconia ligustroides (DC.) Naudin & Border of gallery forest & Shrub & 24,286 \\
Microlepis oleaefolia (DC.) Triana & Border of gallery forest & Shrub & 24,287 \\
Rhynchanthera dichotoma DC. & Wet open site & Sub-shrub & 24,288 \\
\hline
\end{tabular}




\section{Scanning electron microscopy study} (SEM)

Leaf blade samples were taken from the median third of young and mature functional leaves, situated between the $2^{\text {nd }}$ and $6^{\text {th }}$ nodes from the apical bud downwards. Materials were collected from three specimens of each species and processed for analysis by scanning electron microscopy (SEM). Samples were fixed in glutaraldehyde $(2.5 \%$ with $0.1 \mathrm{M}$ phosphate buffer, at $\mathrm{pH}$ 7.3; overnight at $4^{\circ} \mathrm{C}$ ), dehydrated in a graded alcohol series, critical-point dried (Robards 1978), mounted on aluminum stubs, gold-coated and examined with a Phillips 515 scanning electron microscope.

The terminology employed to describe indumenta follows Payne (1978), Theobald et al. (1979), Wurdack (1986) and Mentink \& Baas (1992).

\section{Results}

The analysis of the leaf surfaces of the species under study revealed the occurrence of 14 different morphological types of indumenta:

\section{Miconia albicans (Sw.) Triana}

Fig. $1 \mathrm{a}-\mathrm{b}$

Type I: Non-glandular, vermiform, ferruginous trichomes (Fig. 1a-b). They occur on the surface of young and mature leaves. On young leaves, they form a dense indumentum on both surfaces. On mature leaves, they form a dense cover on the abaxial surface (Fig. 1a) but are restricted to the midrib region on the adaxial surface (Fig. 1b).

\section{Miconia chamissois Naudin}

Fig. $1 \mathrm{c}-\mathrm{d}$

Type II: Sessile to short-stalked nonglandular stellate trichomes, covered with alveolar cuticle (Fig. 1c-d); they are present on both surfaces of young leaves, and distributed along the veins and the intercostal regions. Mature leaves are glabrous.

\section{Miconia fallax DC.}

Fig. 1 e-f

Type III: Sessile to short-stalked non-glandular stellate trichomes (Fig. 1e-f); occurring on both surfaces of young leaves and on the abaxial surface of mature leaves, forming a dense cover. They are predominantly distributed in the intercostal regions.

\section{Miconia ligustroides (DC.) Naudin}

Fig. 2 a-f

Type IV: Glandular trichomes, predominantly short-stalked, prostrate, with an elongated, slightly roughened, multicellular glandular head (Fig. 2a-c). On young leaves, they are abundant in the intercostal region of the abaxial surface (Fig. 2a). On mature leaves (Fig. 2b), they occur on both surfaces and are distributed along the veins and in the intercostal regions.

Type V: Lateral glands (Fig. 2a-e). A mixed type of hair formed by glandular and non-glandular portions; the non-glandular portion is usually branched and may present different degrees of development (Fig. 2c-e). Always prostrate, the glandular portion consists of a short or long stalk and an elongated, biseriate glandular head (Fig. 2ce). In the intercostal regions of the abaxial surface of young leaves, hairs present a poorly developed, often bifurcated non-glandular portion (Fig. 2c-d). Trichomes whose non-glandular portion is highly developed and branched occur predominantly on the veins of the abaxial surface of young leaves (Fig. 2a, e) and on the adaxial surface of mature leaves (Fig. 2b).

Type VI: Non-glandular emergences with a multiseriate wide base and piercing apices (Fig. $2 \mathrm{~b}, \mathrm{f})$. They occur along the margins of young and mature leaves.

Microlepis oleaefolia (DC.) Triana Fig. 3a-c

Type VII: Dendritic, long-stalked, multiseriate non-glandular hairs, uniformly branched (Fig. 3a). They occur on the abaxial surface of young and mature leaves and are distributed over the whole surface.

Type VIII: Dendritic, predominantly shortstalked, non-glandular emergences, uniformly branched (Fig. 3b). They occur on the adaxial surface of young and mature leaves, where they form a dense cover.

Type IX: Glandular, short-stalked hairs with a multicellular glandular head (Fig. 3c). They occur on the abaxial and adaxial surface of both young and mature leaves.

\section{Rhynchanthera dichotoma (Desr.) DC.}

Fig. 3d-h; 4a-g

Type X: Glandular, long-stalked emergences with a pedestal base and a multiseriate, ovate multicellular glandular head (Figs. 3d-g; 4a, f). They are present on both surfaces of young and mature leaves, distributed along the veins and in the intercostal regions. Visible to the naked eye, they stand out by their reddish color due to abundant anthocyanins.

Type XI: Glandular, long-stalked emergences with a pedestal base and a multiseriate, branched multicellular glandular head (Fig. 4a-d). The 

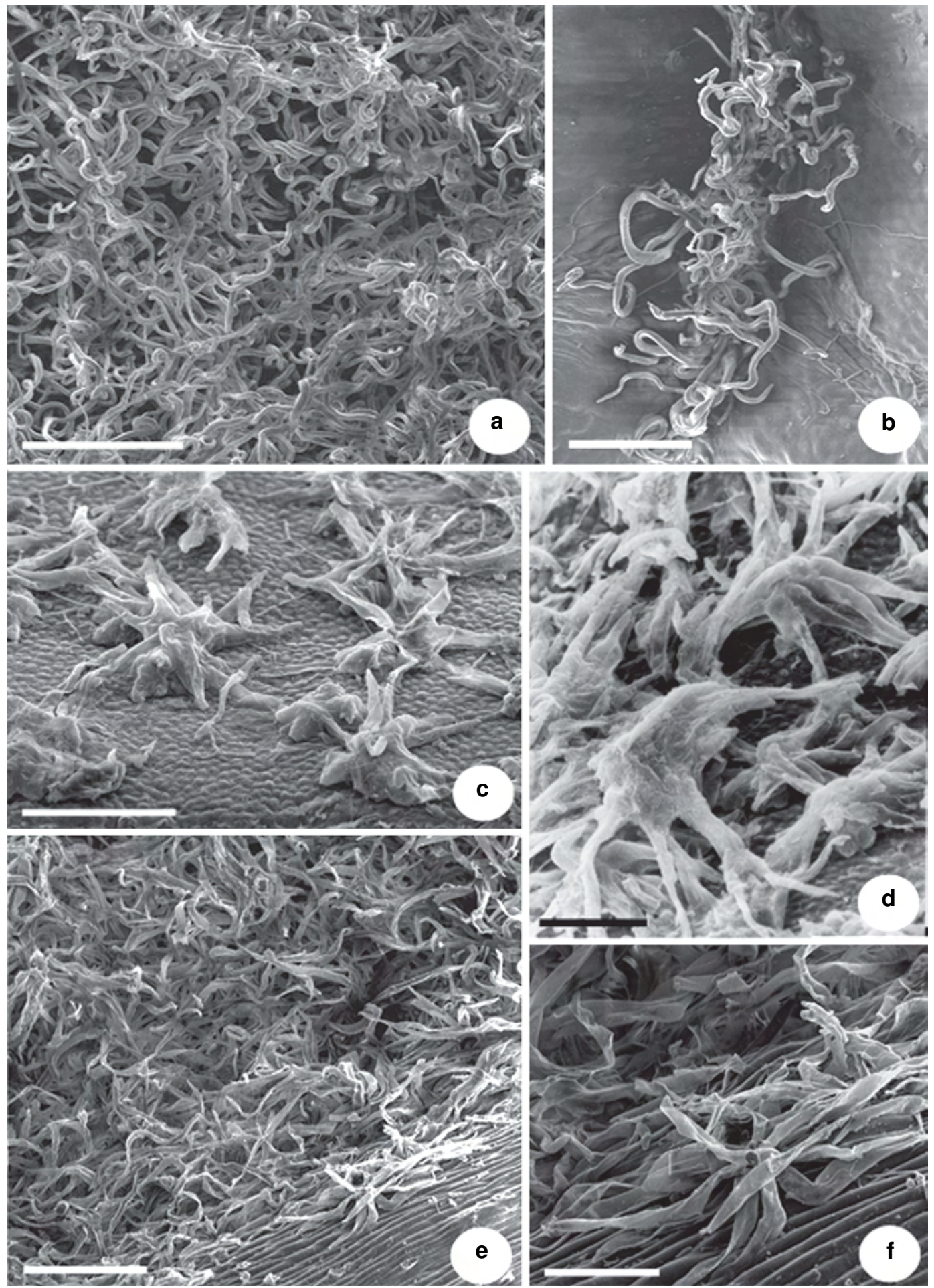

Figure 1 - a-f. Leaf indumentum of Melastomataceae from cerrado. a-b. Mature leaf of Miconia albicans - a. abaxial surface showing vermiform trichomes; b. adaxial surface showing trichomes restricted to midrib. $c-d$. Young leaf of Miconia chamissois - c. abaxial surface showing non-glandular, stellate trichomes covered with alveolar cuticle; d. detail of trichomes. e-f. Mature leaf of Miconia fallax - e. abaxial surface showing dense indumentum; f. detail of non-glandular, stellate trichomes. Scale bars: $\mathrm{a}=66.7 \mu \mathrm{m} ; \mathrm{b}=64.5 \mu \mathrm{m} ; \mathrm{c}=71.4 \mu \mathrm{m} ; \mathrm{d}=48.8 \mu \mathrm{m} ; \mathrm{e}=91.2 \mu \mathrm{m} ; \mathrm{f}=62.5 \mu \mathrm{m}$. 


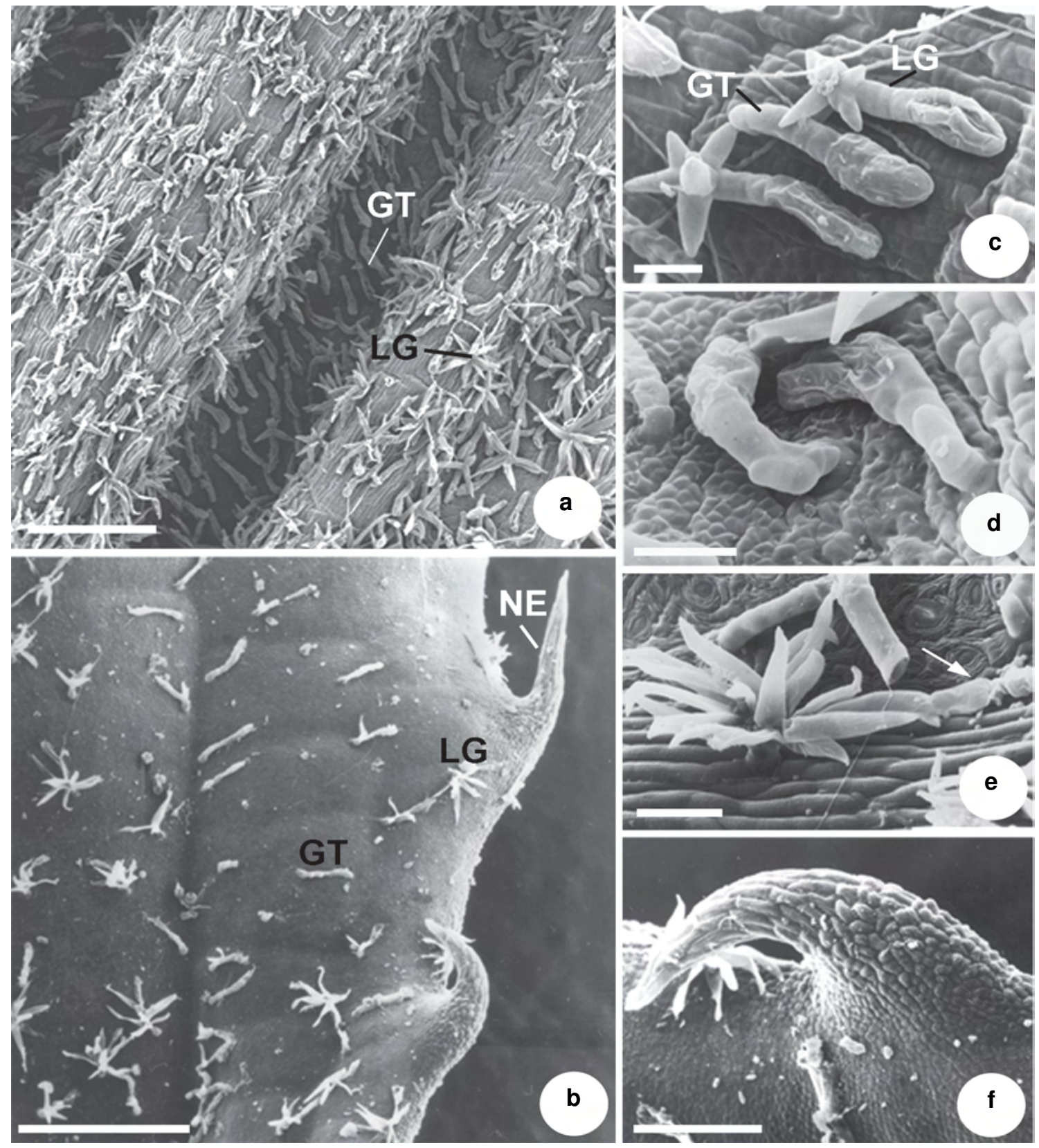

Figure 2 - a-f. Leaf indumentum of Miconia ligustroides - a. abaxial surface of a young leaf showing glandular trichomes and lateral glands; $b$. adaxial surface of a mature leaf showing glandular trichomes, lateral glands and nonglandular emergences; c. detail of a glandular trichome and lateral gland; d. lateral glands showing non-glandular portion slightly developed; e. lateral gland with a highly developed, branched non-glandular portion. The arrow indicates the glandular portion of a lateral gland; f. detail of a non-glandular emergence. (GT = glandular trichome; $\mathrm{LG}=$ lateral gland; $\mathrm{NE}=$ non-glandular emergence). Scale bars: $\mathrm{a}=194.1 \mu \mathrm{m} ; \mathrm{b}=285.7 \mu \mathrm{m} ; \mathrm{c}=23.3 \mu \mathrm{m} ; \mathrm{d}=26.7 \mu \mathrm{m}$; $\mathrm{e}=16.7 \mu \mathrm{m} ; \mathrm{f}=74 \mu \mathrm{m}$. 

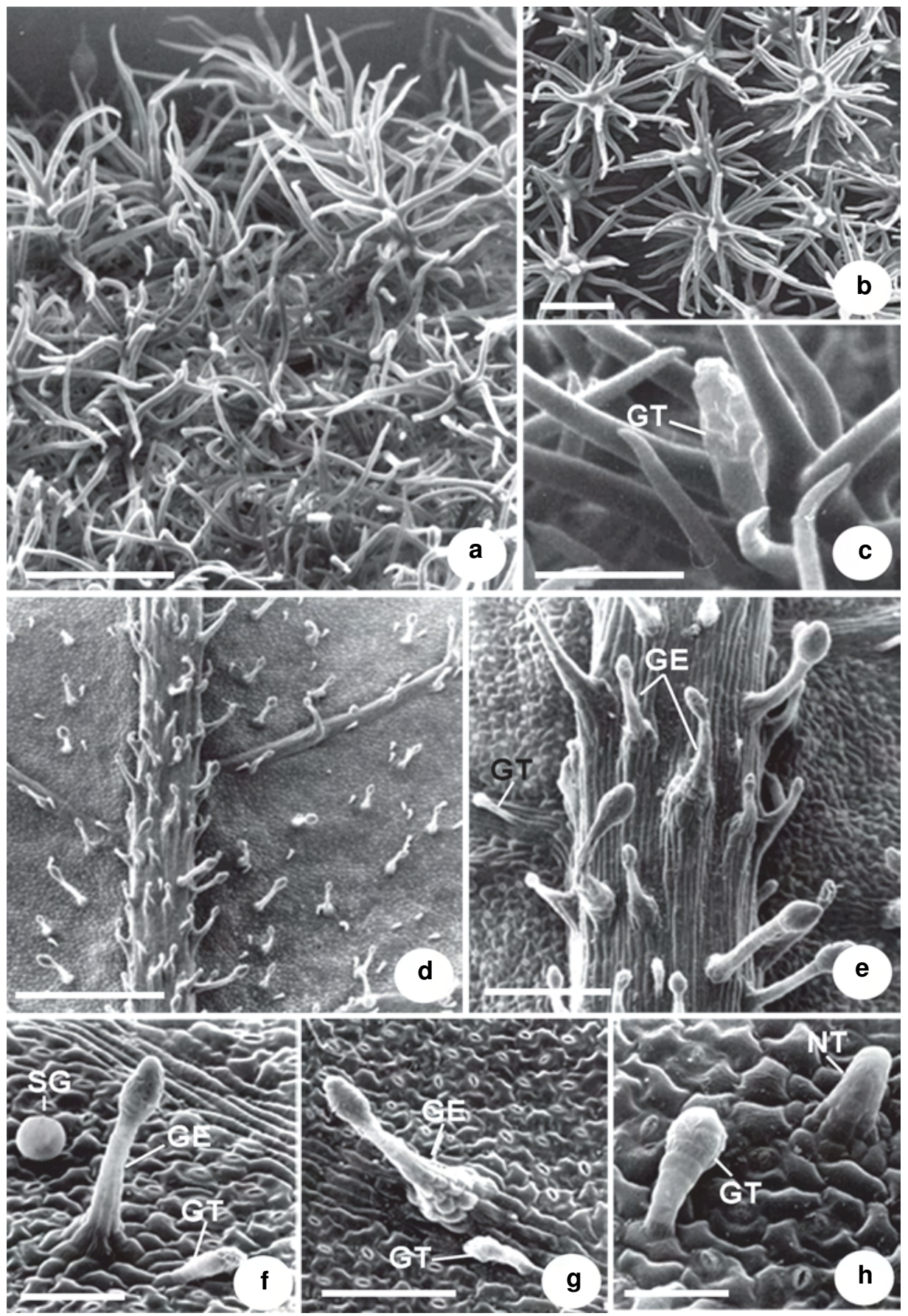

Figure 3 - a-h. Leaf indumentum of Melastomataceae from cerrado. a-c. Mature leaf of Microlepis oleaefolia-a. abaxial surface showing dense indumentum composed of dendritic, long-stalked trichomes; b. adaxial surface covered with dendritic, non-glandular emergences; c. detail of a glandular trichome on the adaxial surface. d-h: Abaxial surface of a mature leaf of Rhynchanthera dichotoma - d. general aspect; e. detail of the previous figure, showing long-stalked glandular emergences, and a glandular trichome; f. aspects of glandular emergence, glandular trichome, and sessile gland on the intercostal region; g. aspects of glandular emergence with a pedestal base, and glandular trichome on a secondary vein; h. detail of a non-glandular trichome and a glandular trichome. (GE = glandular emergence; GT = glandular trichome; $\mathrm{NT}=$ non-glandular trichome; $\mathrm{SG}=$ sessile gland). Scale bars: $\mathrm{a}=105.3 \mu \mathrm{m} ; \mathrm{b}=51.3 \mu \mathrm{m} ; \mathrm{c}=27.8 \mu \mathrm{m} ; \mathrm{d}=645.2 \mu \mathrm{m}$; $\mathrm{e}=166.7 \mu \mathrm{m} ; \mathrm{f}=47.6 \mu \mathrm{m} ; \mathrm{g}=91 \mu \mathrm{m} ; \mathrm{h}=25.6 \mu \mathrm{m}$. 

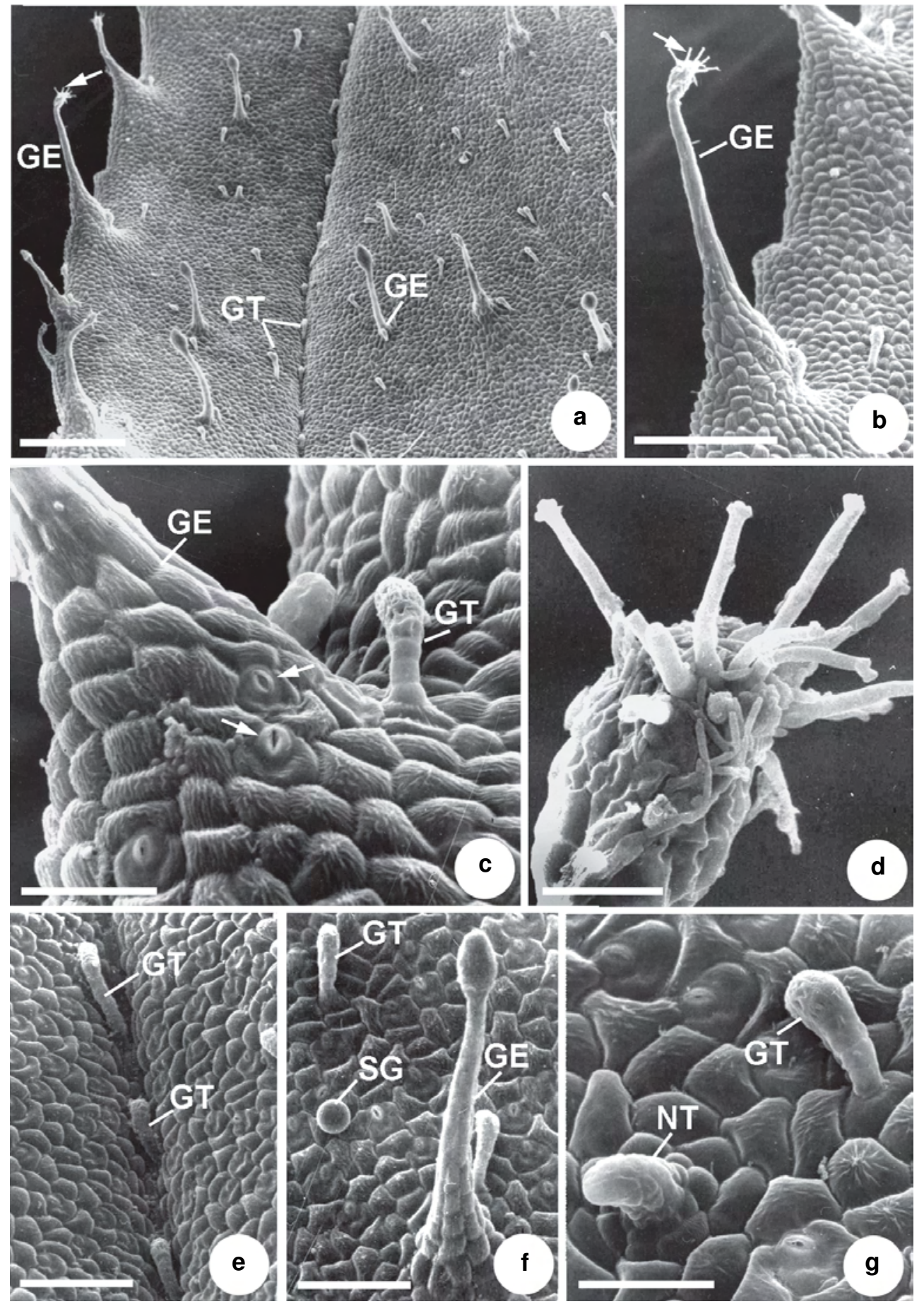

Figure 4 - a-g. Indumentum abaxial surface of a mature leaf of Rhynchanthera dichotoma - a. general aspect showing a variety of trichomes and emergences; $b$. detail of a long-stalked emergence with a branched glandular head (arrow); c. detail of the base of a glandular emergence, showing stomata (arrows). Note glandular trichome; d. detail of the branched glandular head of an emergence; e. glandular trichomes distributed along a secondary vein; f. glandular trichome, sessile gland and glandular emergence distributed along the intercostal region; g. detail of a non-glandular trichome and a glandular trichome. $(\mathrm{GE}=$ glandular emergence; $\mathrm{GT}=$ glandular trichome; $\mathrm{NT}=$ non-glandular trichome; $\mathrm{SG}=$ sessile gland). Scale bars: $\mathrm{a}=400 \mu \mathrm{m} ; \mathrm{b}=166.7 \mu \mathrm{m} ; \mathrm{c}=38.5 \mu \mathrm{m} ; \mathrm{d}=18.9 \mu \mathrm{m} ; \mathrm{e}=87 \mu \mathrm{m} ; \mathrm{f}=91.5 \mu \mathrm{m} ; \mathrm{g}=35.1 \mu \mathrm{m}$. 
presence of stomata at the base of these emergences is commonly observed (Fig. 4c) along the margins of young and mature leaves. Visible to the naked eye, their reddish color is due to abundant anthocyanins.

Type XII: Claviform, short-stalked glandular hairs with a multicellular glandular head (Figs. 3e-h; $4 \mathrm{a}, \mathrm{c}, \mathrm{e}-\mathrm{g})$, occurring on both surfaces of young and mature leaves.

Type XIII: Spherical, sessile glands (Figs. 3f; 4f) present on both surfaces of young and mature leaves, except on the veins.

Type XIV: Short, multiseriate, erect (Fig. 3h) or declined (Fig. 4g) non-glandular hairs observed in the intercostal regions of both surfaces of young and mature leaves.

\section{Discussion}

Trichomes were usually denser on the young leaves of all the species studied here. The functions and adaptive value of trichomes include protection against solar radiation, reduction of water loss, protection against predators, and physical control of materials and metabolic regulation (Johnson 1975). Therefore, the presence of a dense indumentum on young leaves which are frequently devoid of other types of protection, such as waxy deposits or lignified tissues, for example, may represent an important factor of adaptation to the Cerrado conditions of intense solar radiation and high temperatures (Coutinho 2002; Oliveira \& Marquis 2002). On the other hand, the highly reflexive adaxial surfaces of glabrous mature leaves, as observed in Miconia albicans, M. chamissois and M. fallax can act analogously to trichomes and reflect a large part of the incident light, thus being of great value to protect against excessive insolation, desiccation and thermal variations (Hallé et al. 1978; Ehleringer \& Mooney 1984).

The results of this study corroborate previous reports on the wide diversity of indumenta and the predominance of varied and complex forms of hairs among Melastomataceae (Solereder 1908; Metcalfe \& Chalk 1950; Wurdack 1986; Guimarães et al. 1999).

Rhynchanthera dichotoma presented a great morphological variety of foliar indumenta, and four morphological types of hairs are described for the first time: glandular claviform trichomes; long-stalked glandular emergences with branched multicellular glandular heads; sessile glands; and short, multiseriate nonglandular trichomes. Wurdack (1986) recorded the occurrence of long-stalked glands with thinwalled heads on the hypanthium and the adaxial surface of leaves of $R$. dichotoma. The sessile and spherical glands observed on the surface of $R$. dichotoma leaves are similar to the trichomes described by Metcalfe \& Chalk (1950) as "bladder-like glands". These glands are similar to the pearl-like ones observed in Piper regnellii, which were related to mucilage and protein secretion (Silva \& Machado 1999).

A mixed type of trichome formed by a glandular part and a branched, non-glandular portion similar to a lateral-gland, reported by Wurdack (1986) on the leaves of Miconia glyptophylla and M. plumifera var. bangii, was also observed on the surface of young and mature leaves of Miconia ligustroides. In the present work, the variable degree of ramification of the non-glandular portion was a remarkable feature of these structures. The young leaves of $M$. ligustroides occupy a vertical position, thus exposing the abaxial surface to radiation; on this face, veins are very prominent and exposed to radiation, while the intercostal areas are shadowed and protected from light. The intercostal areas show a predominance of lateral glands whose nonglandular portion was little developed, while the veins showed lateral glands with a highly branched non-glandular portion. Recent studies demonstrated a functional link between UV radiation and drought that acts on the induction of trichome development. UV signal perception can lead to photomorphogenic responses as trichomes differentiation which may confer adaptive advantages under abiotic stress conditions associated with high-light environments, such as water stress (Gitz \& LiuGitz 2003). In our opinion, this is a very interesting species to study trichome morphogenesis.

The presence of vermiform hairs on the abaxial surface of Miconia albicans leaves was also observed by Wurdack (1986). Guimarães et al. (1999) also recorded this type of trichome in Tibouchina chamissoana and T. heteromalla, characterizing them as a tangle of smooth and long hairs present on the abaxial surface of the leaves. According to Baumgratz \& Ferreira (1980), the upper surface of $M$. albicans leaves is glabrous, while its lower surface is pilose. In the present study, we also observed vermiform 
trichomes distributed along the midrib on the adaxial surface of mature leaves. These trichomes are abundant on both surfaces of young leaves and on the abaxial surface of mature leaves.

As for Miconia chamissois, our findings are congruent with previous descriptions classifying the mature leaves of this species as glabrous (Martins et al. 1996; Reis et al. 2005). However, it is worth noting that short stellate trichomes covered with alveolar cuticle are present on both surfaces of young leaves. Miconia fallax showed sessile, short-stalked, stellate non-glandular hairs on both surfaces of young and mature leaves. Martins et al. (1996) described this indumentum as stellate canescent, with the upper surface of the leaf glabrous and the lower surface densely covered with stellate non-glandular hairs. The morphology of the nonglandular trichomes observed on the young and mature leaves of Microlepis oleaefolia is similar to that described by Mentink \& Baas (1992) and Reis et al. (2005).

Considering the species here studied, leaf indumentum constitutes an important instrument to circumscribe genera and species of Melastomataceae, as was pointed out by different authors (Wurdack 1986; Guimarães \& Martins 1997; Guimarães et al. 1999).

\section{Acknowledgments}

We thanks FAPESP for financial support to this study (C.R.D. Milanez scholarship Process DR 03/00958-8 and Biota Program Process 00/ 12469-3), CNPq (Research grant to S.R. Machado) and the technical team of the Institute of Biosciences' Electron Microscopy Center, UNESP Botucatu, SP, Brazil, for their assistance in preparing the samples. We also thank Dr. Angela Borges Martins, from the Institute of Biosciences at UNICAMP, for identifying the botanical material.

\section{References}

Baumgratz, J.F. \& Ferreira, G.L. 1980. Estudo da nervação e epiderme foliar das Melastomataceae do Município do Rio de Janeiro. Gênero Miconia. Seção Miconia. Rodriguésia 32: 161-170.

Clausing, G. \& Renner, S.S. 2001. Molecular phylogenetics of Melastomataceae and Memecylaceae: implications for character evolution. American Journal of Botany 88: 486-498.
Coutinho, M.M. 2002. O bioma cerrado. In: Klein, H.L. Eugen Warming e o cerrado brasileiro, um século depois. Editora Unesp, São Paulo. Pp. 77-92.

Crawley, M.J. 1997. Life history and environment. In: Crawley, M.J. Plant Ecology. Academic Press, New York. Pp. 73-131.

Ehleringer, J.R. \& Mooney, H.A. 1984. Leaf hairs: effects on physiological activity and adaptive value to a desert shrub. Oecologia (Berlin) 37: 183-200.

Franco, A.C. 2002. Ecophysiology of woody plants. In: Oliveira, P.S. \& Marquis, R.J. (eds.). The cerrados of Brazil: ecology and natural history of a neotropical savanna. Columbia University Press, New York. Pp. 178-197.

Gitz, D.C. \& Liu-Gitz, L. 2003. How do UV photomorphogenic responses confer water stress tolerance? Photochemistry and Photobiology 78: 529-534.

Guimarães, P.J.F. \& Martins, A.B. 1997. Tibouchina sect. Pleroma (D. Don) Cogn. (Melastomataceae) no estado de São Paulo. Revista Brasileira de Botânica 20: 11-33.

Guimarães, P.J.F.; Ranga, N.T. \& Martins, A.B. 1999. Morfologia dos tricomas em Tibouchina sect. Pleroma (D. Don) Cogn. (Melastomataceae). Brazilian Archives of Biology and Technology 42: 485-493.

Hallé, F.; Oldeman, R.A.A. \& Tomlinson, P.B. 1978. Tropical trees and forests: an architectural analysis. Springer-Verlag, New York. 441p.

Hammond, C.T. \& Mahlberg, P.G. 1973. Morphology of glandular hairs of Cannabis sativa L. from scanning electron microscopy. American Journal of Botany 60: 524-528.

Johnson, H.B. 1975. Plant pubescence: an ecological perspective. The Botanical Review 41: 233-256.

Köppen, W. 1931. Climatologia con un studio de los climas de la tierra. Fondo de Cultura Económica, Buenos Aires. 320p.

Martins, A.B.; Semir, J.; Goldenberg, R. \& Martins, E. 1996. O gênero Miconia Ruiz \& Pav. (Melastomataceae) no estado de São Paulo. Acta Botanica Brasilica 10: 267-316.

Mendonça, R.C.; Felfili, J.M.; Walter, B.M.T.; Silva Júnior, M.C.; Rezende, A.V.; Filgueiras, T.S. \& Nogueira, P.E. 1998. Flora vascular do Cerrado. In: Sano, S.M. \& Almeida, S.P. Cerrado: ambiente e flora. Embrapa-CPAC, Planaltina. Pp. 289-539.

Mentink, H \& Baas, P. 1992. Leaf anatomy of the Melastomataceae, Memecylaceae, and Crypteroniaceae. Blumea 37: 189-225.

Metcalfe, C.R. \& Chalk, L. 1950. Anatomy of the Dicotyledons: leaves, stems, and wood in relation to taxonomy - with notes on economic uses. 1 ed. Vol. 1. Claredon Press, Oxford. 1498p. 
Oliveira, P.S. \& Marquis, R.J. 2002. The cerrados of Brazil: ecology and natural history of a neotropical savanna. Columbia University Press, New York. $398 \mathrm{p}$.

Payne, W.W. 1978. A glossary of plant hair terminology. Brittonia 30: 239-255.

Reis, C.; Bieras, A.C. \& Sajo, M.G. 2005. Anatomia foliar de Melastomataceae do cerrado do estado de São Paulo. Revista Brasileira de Botânica 28: 451-466.

Robards, A.W. 1978. An introduction to techniques for scanning electron microscopy of plant cells. In: Hall, J.L. Electron microscopy and citochemistry of plant cells. Elsevier, New York. Pp. 343-344.

Sandquist, D.R \& Ehleringer, J.R. 1997. Intraspecific variation of leaf pubescence and drought response in Encelia farinosa associated with contrasting desert environments. New Phytologist 135: 635-644.

Silva, E.M.J. \& Machado, S.R. 1999. Ultrastructure and cytochemistry of the pearl gland in Piper regnellii (Piperaceae). Nordic Journal of Botany 19: 623-634.

Solereder, H. 1908. Systematic anatomy of the Dicotyledons. Claredon Press, Oxford. 1182p.

Theobald, W.L.; Krahulik, J.L. \& Rollins, C. 1979. Trichome description and classification. In: Metcalfe, C.R. \& Chalk, L. (eds.). Anatomy of the dicotyledons. Claredon Press, Oxford. Pp. 40-53.

Uphof, J.C.Th. 1962. Plant hairs. Gebrüder Borntraeger, Berlin. 292p.

Wurdack, J.J. 1986. Atlas of hairs for neotropical Melastomataceae. Smithsonian Contributions to Botany 63: 1-80. 